\title{
E-Wallet in Technology Readiness Index Perspectives and Technical Support
}

\author{
Wika Harisa Putri, Shinta Agustin Tri Novia \\ Accounting Departement \\ Faculty of Economics and Business Janabadra University \\ Yogyakarta, Indonesia \\ wikaharisa@janabadra.ac.id
}

\author{
Nurwiyanta \\ Management Departement \\ Faculty of Economics and Business Janabadra University \\ Yogyakarta, Indonesia \\ nurwiyanta@janabadra.ac.id
}

\begin{abstract}
The use of e-wallets, which are currently very massive in various transactions, raises a clear message that if people must adapt to products of financial technology (fintech). Talking about the readiness for technology adoption, of course, we cannot ignore how the theory of technology readiness and acceptance is supported by sufficient empirical studies that describe various phenomena in various countries and various technology-based products. Technology adoption readiness is widely known and assessed using the Technology Readiness Index, where the concept introduces four main variables that are considered to influence the level of readiness to use technology, namely optimism, innovation, inconvenience and insecurity. However, on a different side, the process of establishing company value continues to develop by increasing technical support to be able to encourage the readiness level of technology acceptance. In the context of e-wallets, which are classified as technology products that are still in their use adjustment period, the researcher wants to see whether the optimism and innovation variables combined with technical support in the form of assurance and reliability can encourage the intention to use ewallets in business transactions.
\end{abstract}

Keywords: Technology Readiness Index, reliabililty, assurance

\section{INTRODUCTION}

The widespread use of technology, especially financial technology, has forced individuals who were initially unprepared to accept cultural changes to become individuals who must instantly become ready to use them. In this condition, there is a pressure that changes the level of acceptance of the technology into readiness, transforming from acceptance [1] to readiness [2].

The transformation process from acceptance to readiness also goes through a long journey of empirical study and theory development. Since Davis (1989) introduced the Technology Acceptance Model, which only proposes two variables, namely ease of use and perceived usefulness as acceptance conditions, then it has developed into Technology Acceptance Model 2 which collaborates the results of thoughts between Venkatesh and Davis (2000) and completes the initial model with several variables [3]. The influence of social processes on individuals such as subjective norms, volunteerism, and self-image and cognitive instrumental processes such as job relevance, quality of outcomes, and ability to show work results. The TAM 2 model emerged from efforts to collaborate with social psychology theories including Theory of Reasoned Action /
TRA [4], Theory of Planned Behavior / TPB [5] coupled with various other social psychological theories.

At the same time as the development of TAM Model 2, the discourse on readiness for technology was introduced by Parasuraman (2000), who tried to bring up several readiness factors that were based on the motivation to provide the best service for its consumers. This initiative becomes natural because Parasuraman is also the one who introduced the SERVQUAL concept [6] [7]. The research objective is to assess the readiness of individuals to interact with technology in the context of the relationship between workers and technology and consumers with technology. This theory describes four main variables that are considered as determinants of technology readiness, namely optimism, innovation power, discomfort and insecurity. This theory continues to be developed to give birth to the concept of Technology Readiness Index 2.0 [8] which still uses the perspective of 4 variables from the concept of Technology Readiness Index 1.0. The difference is in the construct used, from 36 items to only 16 items which are considered stronger.

The development of technology acceptance theory also continues with the birth of the Unified Theory of Acceptance and Use Technology (UTAUT) developed by Venkatesh et al. (2003) [3] which is a refinement of Technology Acceptance Model 2 developed in 2000. In this theory, TAM is enhanced by presenting variables new in the form of performance expectations, business expectations, social influence, conditions that facilitate and try to be combined with several socio-demographic variables such as age, gender, experience and willingness to use technology as antecedents of intention and behavior. This theory has also developed with the birth of the Unified Theory of Acceptance and Use Technology/UTAUT 2 [9], by adding new variables in the form of hedonic motivation, price value, and habits, and eliminating willingness variables.

In particular, in this study, researchers wanted to know how the phenomenon of using e-wallets/electronic wallets in the perspective of technological readiness by its users. Because the use of e-wallets is more likely to aim at comforting consumers (having dimensions of service quality), the researchers used the Technology Readiness Index theoretical approach which was indeed built with a service quality/SERVQUAL approach.

The dimension of technological readiness developed by Parasuraman (2000) has two perspectives, namely, positive and 
negative. Two variables representing a positive perspective are optimism and innovation, and two variables representing a negative perspective are discomfort and insecurity. Because the use of e-wallets is now a necessity in the wider community, the researchers in this study only limit the positive perspective and temporarily hide the negative perspective that accompanies the readiness of technology adoption. Besides, researchers also agree that the need for companies to create new business value for their customers is unavoidable at this time [10], especially in the use and creation of technology that makes it easier for consumers to reach and use their products. For this reason, negative perspectives that may arise from the technology adoption process must be resolved with the help of technical support from goods/service providers [11]. Therefore, the researcher wants to see how the collaboration between the dimensions of technological readiness in a positive perspective (innovation and optimism) with the existence of technical support provided by e-wallet service providers in increasing the creation of business value for customers to influence their behavior in using e-wallets.

Discussions regarding technical support cannot be separated from the company's desire to provide good quality service. This variable was developed from further discussion with the SERVQUAL theoretical framework [6], which presents the five most important aspects of service quality, namely tangibles, reliability, responsiveness, assurance, and empathy. Prior research explores the value attributes that exist in each aspect of service quality, namely knowledge, relationships and access. Of the three value attributes, what can be presented in the form of technical support is the attribute value of knowledge and customer relationships.

Furthermore, details that among the five aspects of service quality, the ones that contain the most valuable attributes of technical support (knowledge and customer relationships) are assurance and reliability [11]. Therefore, this study aims to see the influence between the variables of optimism, innovation (positive perspective of technological readiness) and variables of assurance and reliability as a form of technical support provided by companies for consumers to make it easier to use their products.

This research will specifically discuss the readiness of technology adoption by merchants in using e-wallets to serve sales transactions. The variables to be tested include optimism, innovation, assurance, and reliability on the intention to use ewallets. As it is known, the emergence of various financial technology products (fintech) has forced the readiness of individuals to adopt technology, especially in the trading process. In previous research conducted in Ghana, it showed that the variables of individual innovation and optimism had a positive effect on the adoption of financial technology in the form of payments using e-payments [12]. Similar research that attempts to link optimism and innovation variables to the intention to use m-payment through moderating variables in the form of perceived ease of use and perceived usefulness also shows a positive effect, confirm that optimism and innovation are important antecedents of readiness to use technology [13].

\section{LITERATURE REVIEW AND HYPOTHESIS DEVELOPMENT}

\section{A. Optimism and Intention to Use e-Wallet}

Optimism can be defined as a positive attitude towards technology and believes that technology will increase control, flexibility and efficiency in life [14]. In this study, it was found that optimism has a positive effect on the Technology Readiness Index. Previous research related to the adoption of m-payment in Finland, America, Germany and Japan shows that the two variables affect the perceived ease of use and the perceived usefulness of using m-payment [15]. This finding is reinforced by the following findings that specifically point to the optimism variable as affecting perceived convenience and perceived usefulness [16].

Based on the explanation above and to test whether the perceived ease and usefulness will tend to affect the intention to use, the researchers propose the hypothesis H1: Optimism has a positive effect on the intention to use e-wallets.

\section{B. Innovation and Intention to Use e-Wallet}

Innovation is defined as the result of developing the use/mobilization of knowledge, skills (including technological skills) and experience to create or improve new products and systems, which provide meaningful or significant value [17]. Innovation is also a tendency to be at the forefront of technology [18][8]

Furthermore, Seol (2017) found that something that is developed and improved provides a meaningful value that can affect expectations of increased performance to support the system. Based on the theoretical basis and the findings in these previous studies, it can be concluded that innovation affects expectations of increased performance to support system use. Because e-wallet is a payment system in financial technology, the researcher proposes hypothesis H2: Innovation has a positive effect on the intention to use the e-wallet.

\section{Assurance and Intention to Use e-Wallet}

Assurance is directly related to the person factor. The ability of people (employees/staff) of the company to serve consumers so that trust and confidence are built. This assurance is related to the competence of people in certain fields of work. Assurance also includes the credibility of people in carrying out certain fields of work and courtesy [19] [20]. In a study conducted by Mariska (2016), it was found that assurance did not affect the intention to use e-wallets. However, in previous studies, in the SERVQUAL dimension described by Parasuraman, Zeithaml \& Berry (1991), it was found that the assurance variable is one of the contributors to satisfaction which in turn will affect the intention to use. Because the findings of the two studies are inconsistent, researchers in the context of using e-wallets propose the hypothesis H3: Assurance has a positive effect on the intention to use ewallets.

\section{Reliability and Intention to Use e-Wallet}

Reliability is defined as the company's ability to fulfil promises (promises) completely, precisely, and accurately to consumers, for the products offered. Reliability (trust) is 
directly related to characteristics: the ability to show honesty not lies, the ability to provide consistent service, commitment to providing consistent service. Reliability is the main dimension to form consumer impressions. The company's ability to meet the dimensions of reliability (trust) directly creates customer satisfaction [20]. The results of this study indicate that reliability or reliability has an effect on user satisfaction and is thought to affect the intention to use ewallets. This result is consistent with the research [7] which states that reliability is a variable that influences customer satisfaction. Because the theoretical concept of customer satisfaction raises an association of intention to use, the researcher, in this case, proposes the hypothesis H4: Reliability has a positive effect on the intention to use ewallets.

Overall the hypothesis development can figure in proposed models in this research as follows:

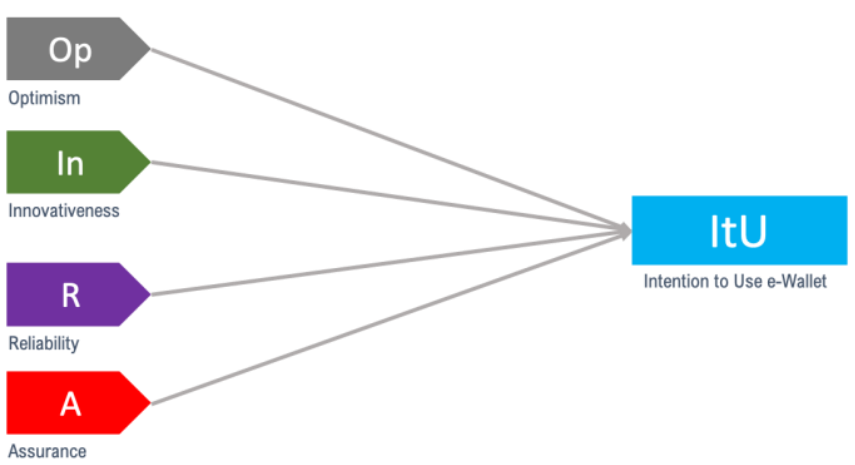

Independent Variable

Dependent Variable

Fig. 1 HYPOTHESIS DEVELOPMENT

\section{METHODOLOGY}

This research developed multi-item measures for each construct through the following process. First, all the constructs and the corresponding measurement items were developed by adapting the relevant and existing literature to suit this study's theme and context. Second, improved by the literature review, twenty-two items for five constructs are finally selected. For all measurement items, a five-point Likert scale was used with anchors ranging from strongly disagree (1) to strongly agree (5). This study analyzed the following two dimension of the technology readiness index: reliability ( 2 items), assurance (6 items), and optimism (5 items) and innovativeness (6 items), and two dimensions of technical support: reliability (5 items), assurance (3 items) which were modified from Gajic \& Boolaky [19] for technical support and Parasuraman \& Colby [21] for technology readiness and two items for dependent variable intention to use were adapt from Venkatesh [3]

\section{A. Scale Development and Data Validation}

The population that is taken is all merchants that provide non-cash payments, especially e-wallet services such as Gopay, OVO, Link Aja, Dana and so on. Meanwhile, the sampling method used in this study was purposive sampling, with samples of merchants selling food and beverages in malls located in DIY Province. Primary data is obtained from respondents in the form of merchants who use e-wallets in their transactions through questionnaires distributed online with google form.

The questionnaire was equally distributed among 215 respondent, and 202 valid questionnaires were returned. After discarding the redundant and incomplete questionnaires, the effective sample size was 190. Tables 1 lists the sample demographics. In order to ensure the internal reliability and consistency of the constructs, Cronbach's alpha was computed for all the constructs. The values of the constructs ranged from the 0.7 to the 0.9 . It ensured that all the items in the constructs were reliable and valid.

TABLE I. DEMOGRAPHIC ATRIBUTES FOR THE RESPONDENT

\begin{tabular}{|l|c|c|}
\hline \multicolumn{1}{|c|}{ Characteristic } & N= 190 & \% \\
\hline Gender & & \\
Male & 86 & 45.26 \\
Female & 104 & 54.74 \\
\hline Age & 12 & \\
under 20 & 68 & 6.31 \\
$21-30$ & 52 & 35.79 \\
$31-40$ & 41 & 27.37 \\
$41-50$ & 17 & 8.58 \\
51 above & & \\
e-Wallet & 88 & 46.31 \\
Gopay & 46 & 24.21 \\
OVO & 23 & 12.11 \\
LinkAja & 21 & 11.05 \\
Dana & 12 & 6.32 \\
Others & & \\
\hline Education & 58 & 30.52 \\
High school or below & 64 & 33.68 \\
Diploma & 56 & 29.48 \\
Bachelor & 12 & 6.31 \\
Master or above &
\end{tabular}

\section{B. Data Processing}

The data were analyzed in SPSS using internal validity and reliability. For this purpose, the Cronbach's alpha value was checked against each construct as can be seen in Table 2 . After analyzing the reliability of the constructs, multiple linear regression analysis was conducted to test the impact between independent and dependent variables.

TABLE II. VALIDITY AND RELIABILITY

\begin{tabular}{|l|c|c|c|}
\hline Constructs & Items & $\begin{array}{c}\text { Pearson } \\
\text { Correlation }\end{array}$ & $\begin{array}{c}\text { Cronbach } \\
\text { alpha }\end{array}$ \\
\hline Innovative & IN1 & .630 & .767 \\
\hline & IN2 & .645 & \\
\hline & IN3 & .796 & \\
\hline & IN4 & .751 & \\
\hline & IN5 & .710 & \\
\hline Optimism & OP1 & .723 & .769 \\
\hline & OP2 & .780 & \\
\hline & OP3 & .728 & \\
\hline & OP4 & .693 & \\
\hline & OP5 & .704 & \\
\hline Reliability & R1 & .897 & .753 \\
\hline & R2 & .885 & \\
\hline Assurance & A1 & .743 & .842 \\
\hline & A2 & .803 & \\
\hline & A3 & .769 & \\
\hline & & & \\
\hline
\end{tabular}




\begin{tabular}{|l|c|c|c|}
\hline & A4 & .815 & \\
\hline & A5 & .730 & \\
\hline & A6 & .752 & \\
\hline ItU & ItU1 & .808 & .747 \\
\hline & ItU2 & .874 & \\
\hline & ItU3 & .761 & \\
\hline
\end{tabular}

Before interpreting the regression results, basic assumptions underlying the model were checked. For example, there should not be any multicollinearity. This assumption is checked in SPSS with the variance inflation factor (VIF) and tolerance (1/VIF). A second assumption is a homoscedasticity. This result can be checked by making regression plots of the residuals. The graph shows homoscedasticity if the dots are evenly dispersed, and heteroscedasticity if it funnels out. There seems to be no funnel in the regression plots of the predictors in this research, so it can be concluded that homoscedasticity condition is also met. Next, the assumption of independent errors, or a lack of autocorrelation, can be tested with the Durbin-Watson test. The Durbin-Watson test value is 1.95, which is so close to 2 that the assumption has certainly been met. The last assumption is that the errors should be normally distributed, which can be checked by the Kolmogorov-Smirnov test. The K-S test value is 0.439 , above 0.05 as normality value standard, based on which it can be concluded that the errors are normally distributed. All the basic test, as shown in Table 3 as follows:

TABLE III. MULTICOLLINEARITY, NORMALITY, AUTO-CORRELATION, AND HETEROSKEDASTICITY

\begin{tabular}{|c|c|c|}
\hline $\begin{array}{l}\text { Normality test with One-Sample } \\
\text { Kolmogorov-Smirnov Test }\end{array}$ & \multicolumn{2}{|c|}{$\mathbf{N}=190$} \\
\hline $\begin{array}{l}\text { Kolmogorov-Smirnov Z } \\
\text { Asymp. Sig. (2-tailed) } \\
\text { Test distribution is Normal } \\
(.439>.05)\end{array}$ & \multicolumn{2}{|c|}{.439} \\
\hline Multicollinearity test with & \multicolumn{2}{|c|}{ Collinearity Statistics } \\
\hline Variance Inflation Factor (VIF) & Tolerance & VIF \\
\hline $\begin{array}{l}\text { Innovative } \\
\text { Optimism } \\
\text { Reliability } \\
\text { Assurance } \\
\text { Dependent variable: } \\
\text { Intention to Use } \\
\text { VIF value is feasible if below } 10\end{array}$ & $\begin{array}{l}.650 \\
.692 \\
.669 \\
.598\end{array}$ & $\begin{array}{l}1.538 \\
1.444 \\
1.495 \\
1.672\end{array}$ \\
\hline \multicolumn{3}{|c|}{ Heteroskedasticity test with Scatterplot } \\
\hline 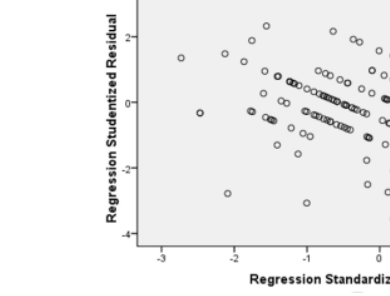 & $\frac{1}{i}$ & \\
\hline \multicolumn{3}{|c|}{ Autocorrelation test with Durbin Watson } \\
\hline $\mathrm{R}$ square & $\begin{array}{l}\text { Adjusted } \\
\text { R2 }\end{array}$ & DW \\
\hline .465 & .453 & 1.951 \\
\hline
\end{tabular}

After testing all assumptions, it was concluded that all assumptions for generalization have been met and sufficient to carry out to hypothesis and model testing

\section{DisCUSSION AND CONCLUSION}

\section{A. Research Findings}

Model in Table 4 shows that all the independent variables are significant except the reliability. The partial regression coefficients show the part of the variation caused in the explained variable, intention to use, by a one-unit change in the predicted variables, i.e., innovative, optimism, and assurance. The strongest predictor is the innovative $(\beta=0.354)$ of the ewallet application towards intention to use. The next variable that strongly affects the intentions is optimism $(\beta=0.334)$. The assurance, as technical support construct is also significant $(\beta$ $=0.220)$. Reliability is statistically insignificant, and the part of the variation caused in the predicted variable, intention to use, is also low $(\beta=-.116)$.

Based on the result in Table 4, show that innovative, optimism and assurance have a positive effect on the intention to use an e-wallet so that we can conclude that hypothesis 1,2 and 4 supported in this research.

TABle IV. Result OF Multiple REgRESSION

\begin{tabular}{|c|c|c|c|c|c|}
\hline \multirow{2}{*}{$\begin{array}{c}\text { Independent } \\
\text { Variables }\end{array}$} & \multicolumn{2}{|c|}{$\begin{array}{l}\text { Unstandardized } \\
\text { coefficients }\end{array}$} & \multirow{2}{*}{$\begin{array}{c}\text { Standardized } \\
\text { coefficient } \\
(\beta)\end{array}$} & \multirow[t]{2}{*}{$\mathbf{t}$} & \multirow[t]{2}{*}{ Sig } \\
\hline & B & SE & & & \\
\hline Constant & -1.297 & .960 & & -1.351 & .178 \\
\hline Innovative & .227 & .043 & .354 & 5.303 & .000 \\
\hline Optimism & .257 & .050 & .334 & 5.173 & .000 \\
\hline Reliability & -.193 & .110 & -.116 & -1.756 & .081 \\
\hline Assurance & .145 & .046 & .220 & 3.164 & .002 \\
\hline
\end{tabular}

The $\mathrm{R}$ square in the Table 3 shows that the $45.3 \%$ variation in the predicted variable, intention to use, has been explained by the predictors, innovative, optimism, reliability, and assurance. Model fit estimates will be analyzed and interpreted with $\mathrm{F}$ test as shown in Table 5 as follows:

TABLE V. Model FIT USING F TEST

\begin{tabular}{|c|r|r|r|r|r|}
\hline Model & $\begin{array}{c}\text { Sum of } \\
\text { Square }\end{array}$ & \multicolumn{1}{c|}{ df } & Mean square & F & Sig \\
\hline Regression & 336.283 & 4 & 84.071 & 40.128 & .000 \\
Residual & 387.591 & 185 & 2.095 & & \\
Total & 723.874 & 189 & & & \\
\hline
\end{tabular}

Predictors: Innovative, Optimism, Assurance

Dependent Variable: Intention to Use

According to the result as shown in Table 5, we can say that all predictors simoultanly predicts dependent variable.

This research shows that innovativeness and optimism, as determinants in technology readiness supported intention to use e-wallets, because, without sufficient readiness in technology, somebody cannot use an e-wallet and optimized the featured available. Besides, the intention also supported with technical support from an e-wallet service provider, 
especially the support that assurance such as sharing their knowledge about the e-wallet feature, and solving their specific problems accurately. This study will be beneficial for the service providers to make a continuous improvement in maximizing e-wallet featured and introduce their recent work massively to the e-wallet user.

\section{ACKNOWLEDGMENT}

Thank you to Faculty of Economics and Business Janabadra University which has provided funding support for this research in the competitive research scheme.

\section{REFERENCES}

[1] F. D. Davis, Perceived Usefulness, Perceived Ease of Use, and User Acceptance of Information Technology, MIS Q., vol. 13, no. 3, 1989, pp. 319-340.

[2] A. Parasuraman, Technology Readiness Index (TRI): A Multiple item Scale To Measure Readiness To Embrace New Technologies, J. Serv. Res., vol. 2:307, no. May, 2000.

[3] V. Venkatesh, M. G. Morris, G. B. Davis, and F. D. Davis, User Acceptance of Information Technology: Toward a Unified View, MIS $Q$. , vol. 27, no. 3, 2003, pp. 425-478.

[4] M. Fishbein and I. Ajzen, Belief, attitude, intention and behavior: An introduction to theory and research. Addison-Wesley, 1975.

[5] I. Ajzen, The Theory of Planned Behavior, 1991.

[6] A. Parasuraman, V. A. Zeithaml, and L. L. Berry, A Conceptual Model of Service Quality and Its Implications for Future Research, J. Mark., vol. 49 , no. 4 , 1985 , p. 41

[7] A. A. Parasuraman, V. A. Zeithaml, and L. L. Berry, Refinement and reassessment of the SERVQUAL instrument, J. Retail., vol. 67, no. 4, 1991, pp. 420-450.

[8] A. Parasuraman and C. L. Colby, An Updated and Streamlined Technology Readiness Index: TRI 2.0, J. Serv. Res., vol. 18, no. 1, 2015, pp. 59-74.

[9] V. Venkatesh;, J. Y. L. Thong;, and X. Xu, Consumer Acceptance and Use of Information Technology: Extending the Unified Theory of
Acceptance and Use of Technology, MIS Q., vol. 36, no. 1, 2012, pp. $157-178$.

[10] C. Grönroos, Service logic revisited: Who creates value? And who cocreates?, Eur. Bus. Rev., vol. 20, no. 4, 2008, pp. 298-314.

[11] N. Gajic and M. Boolaky, Impact of technical support on customer satisfaction: Case of automotive paints, SAGE Open, vol. 5, no. 4, 2015.

[12] P. Acheampong, L. Zhiwen, H. A. Antwi, A. Akai, A. Otoo, and W. G. Mensah, Hybridizing an Extended Technology Readiness Index with Technology Acceptance Model ( TAM ) to Predict E-Payment Adoption in Ghana, Am. J. Multidiscip. Res., vol. 5, no. 2, 2017, pp. 172-184.

[13] M. Martens, O. Roll, and R. Elliott, Testing the Technology Readiness and Acceptance Model for Mobile Payments Across Germany and South Africa, Int. J. Innov. Technol. Manag., vol. 14, no. 6, 2017.

[14] M. Y. Florestiyanto, Evaluasi Kesiapan Pengguna Dalam Adopsi Sistem Informasi Terintegrasi Di Bidang Keuangan Menggunakan Metode Technology Readiness Index, Semin. Nas. Inform., vol. 1, no. 4, 2012, pp. 288-296.

[15] N. Guhr, T. Loi, R. Wiegard, and M. H. Breitner, Technology Readiness in Customers 'Perception and Acceptance of M(obile ) -Payment: An Empirical Study in Finland, Germany, the USA and Japan, in International Conference on Wirtschaftsinformatik, 2013, no. March, pp. $119-133$.

[16] P. Godoe and T. . Johansen, Understanding adoption of new technologies: Technology readiness and technology acceptance as an integrated concept, J. Eur. Psychol. Students, vol. 3, no. 1, 2012, pp. 38 52.

[17] S. H. Seol, D. S. Ko, and I. S. Yeo, Ux analysis based on TR and UTAUT of sports smart wearable devices, KSII Trans. Internet Inf. Syst., vol. 11, no. 8, 2017, pp. 4162-4179.

[18] A. Parasuraman, Technology Readiness Index (Tri): A Multiple-Item Scale to Measure Readiness to Embrace New Technologies, J. Serv. Res., 2000.

[19] N. Gajic and M. Boolaky, Impact of technical support on customer satisfaction: Case of automotive paints, SAGE Open, vol. 5, no. 4, 2015.

[20] Z. Mariska and M. Shihab, Pengaruh Dimensi Service Quality Terhadap Kepuasan Tamu Hotel dan Dampaknya Terhadap Behaviour Intention (Studi Kasus Pada Hotel Aston Kuningan Suites-Jakarta), J. Manaj. Dan Bisnis Sriwij., vol. 14, no. 2, 2016, pp. 217-234.

[21] A. Parasuraman and C. L. Colby, An Updated and Streamlined Technology Readiness Index: TRI 2.0, J. Serv. Res., vol. 18, no. 1, Feb. 2015, pp. 59-74. 